\title{
Characterization of Bioactive Compounds from Romanian Cetraria islandica (L) Ach.
}

\author{
SIMONA PATRICHE ${ }^{1}$, IOANA OTILIA GHINEA ${ }^{1}$, GIGI ADAM ${ }^{2}$, GABRIELA GURAU², BIANCA FURDUI ${ }^{1}$, RODICA MIHAELA DINICA $^{1 *}$, \\ LAURA-FLORENTINA REBEGEA², MARIANA LUPOAE ${ }^{2}$ \\ 'Dunarea de Jos University of Galati, Faculty of Science and Environment, Chemistry, Physics and Environment Department, \\ 47 Domneasca Str., 800008, Galati, Romania \\ 2Dunarea de J os University Galati, Faculty of Medicine and Pharmacy, 35 Al. I. Cuza Str, 800010, Galati, Romania
}

\begin{abstract}
Lichens ( Lichenophyta phylum), the least exploited subdivision of fungus, are composite plants used in folk medicine for the treatment of diverse pathologies, from respiratory to digestive diseases, as they contain over 500 potentially bioactive compounds identified up-to-date. Lichen acids, such as usnic acid, lobar acid, lecanoric acid or salazinic acid, are among these compounds, with biopharmaceutical applications as antimicrobial, antioxidant and cytotoxic agents. The objectives of this study were to extract usnic acid from Romanian Cetraria islandica, (Parmeliaceae family), to characterize the extracts and to evaluate their antioxidant and antimicrobial potential. The extracts were characterized using FTIR spectroscopy and HPTLC techniques. The extracts and pure usnic acid have shown high antioxidant activity and have activity against certain Gram-positive and Gram-negative bacteria and fungi such as Candida albicans. Therefore, the analyzed bioactive compounds could be used as the basis of pharmaceutical formulations to treat various respiratory and digestive disorders.
\end{abstract}

Keywords: lichens, usnic acid, IR spectroscopy, HPTLC, antioxidant, antimicrobial

Lichens are complex symbiotic associations between a fungus (mycobiont) and an alga (photobiont) used in traditional medicine for various diseases due to the presence of several bioactive compounds in their structure [1]. Cetraria islandicalichen is one of the mostused species to treat tuberculosis, acute respiratory diseases, especially those of upper tract, inflammation of the throat and oral cavity, stomach and duodenal ulcers [2]. Furthermore, Cetraria islandica has a significant role to reduce the acidity and adjust the digestion and the absorption after severe illnesses or surgeries [3]. 700 compounds are found in lichen structure, of which about 200 are depside and over 100 compounds are depsidone [4]. In addition, in the structure of this plant, certain chemical elements, organic compounds, polysaccharides, carotenoids and other substances have been identified [3, 4]. Lichen compounds can be arbitrarily divided into two groups: primary and secondary compounds. Primary lichen compounds have structural functions and are involved in cell metabolism. Secondary lichen compounds are characterized by acid properties, such as lichen acids $[5,6]$. Each species of lichen has its own set of lichen acids, which generally give qualitative reactions enabling the lichen species to be discriminated. A lot of lichen species contain atranorin, usnic acid, lecanoric acid, salazinic acid, lobar acid and other acids [7]. Lichen acids are important not only to identify the lichens, but also could be used as natural antibiotics $[8,9]$. Therefore, the bioactive compounds from lichens have various biopharmaceutical applications as antimicrobial, antioxidant and cytotoxic agents, being used in the development of new formulations or technologies for the benefit of human life [10].

Lichens are vegetable products with a significant antioxidant [11], antimicrobial [12], anti-proliferative [13], antifungal [14] and UV filter activity [15], belonging to the Lichenophyta phylum, which is the least exploited subdivision of fungus [16, 17]. In this article, chemical and biological studies of the bioactive compounds from a native species of lichens, Cetraria islandica, from the Cetraria genus (Parmeliaceae family) [18] were carried out. The analyzed bioactive compounds are responsible for the antioxidant and antimicrobial properties of this vegetable and play an important role to treat various respiratory and digestive diseases and to improve bronchial disorders [ 19, 20].

\section{Experimental part \\ Plant material}

In this study, local plant material represented by thallus of Cetraria islandica lichen was used. The plant material was harvested from the spontaneous flora of Fagaras Mountains (Romania) in May 2015. Macroscopic analysis of the plant product was done by inspecting the structural appearance of erect lobes of the thallus, which were about $10 \mathrm{~cm}$ tall. To perform further analysis, the lobes were divided in two, being flat and twist and with thick and rigid cilia on the edge. The upper face of thallus was characterized by a glossy greenish-brown color, while the underside showed a white-gray, reddish color at the insertion site of the substrate. Morphological characteristics of the plant material were investigated by smell and taste perception. Thus, the thallus of $C$. islandicalichen has bitter taste and weak odor.

\section{Extraction of furan derivatives from plant material}

$50 \mathrm{~g}$ samples of dry and ground plant material were extracted with $250 \mathrm{~mL}$ acetone and $250 \mathrm{~mL}$ ethanol $95 \%$, respectively under continuous stirring for 3 hours at $50^{\circ} \mathrm{C}$. The extracts were concentrated to $10 \mathrm{~mL}$. The acetone extract was precipitated with benzene to obtain usnic acid as a white-yellow precipitate that was dried in the oven. $200 \mathrm{mg}$ of usnic acid was obtained.

\section{Infrared spectroscopy}

The transmittance values in infrared were obtained in range of $4000-400 \mathrm{~cm}^{-1}$ using Attenuated Total Reflectance Fourier Transform Infrared Spectroscopy (ATR-FTIR) [21] performed with Nicolet iS50 ATR equipment at room temperature. 
Quantitative evaluation of usnic acid

The quantitative evaluation of usnic from acetone extract of $C$. islandica lichen was perfomed by HPTLC technique using Linomat IV equipment (Camag). The two extracts of lichen and standard solution of usnic acid in various concentrations were spotted on silica gel chromatographic plate $\left(60, \mathrm{~F}_{254}\right)$ of $10 \times 10 \mathrm{~cm}$. The plate was eluted in the chromatographic mobile phase, toluene: dioxane: acetic acid (180:45:5) and dried for 5 minusing TLC dryer from Linomat IV equipment. The qualitative evaluation of colored bands was performed using Camag TLC scanner II.

\section{Antioxidant activity evaluation}

The antioxidant activity of the extracts of $C$. islandica lichen was determined using the radical scavenging capacity assay, the reducing power of the extracts and the hydrogen peroxide $\left(\mathrm{H}_{2} \mathrm{O}_{2}\right)$ scavenging capacity of the extracts, respectively.

\section{Reducing power assay}

The reducing power of the two lichen extracts (acetone and ethanol) was evaluated using the method of Yang, Guo and Yuan [22], with some modifications. Rutin in concentration of $0.1 \mathrm{~g} / 100 \mathrm{~mL}$ was used as standard according to the modified method. Samples were measured spectrophotometrically at $420 \mathrm{~nm}$. Each test was performed in triplicate.

\section{DPPH radical scavenging activity}

The scavenging capacity assay was evaluated according to the method of Bozin et al [23], with some modifications [24, 25], using 2,2-diphenyl-1-picrylhydrazyl radical (DPPH). $1 \mathrm{~mL}$ of lichen extracts were mixed with $1 \mathrm{~mL}$ of $90 \mathrm{iM} \mathrm{DPPH}$, being brought with $\mathrm{MeOH}$ at final volume of $4 \mathrm{~mL}$. The same procedure was used to obtain the blank test solution. The solutions were kept for 1 hour at room temperature and the absorbance was recorded at $517 \mathrm{~nm}$. Each test was performed in triplicate. The radical scavenging capacity was calculated using the equation:

$$
\operatorname{RSC}(\%)=100 \times\left(A_{\text {blank }}-A_{\text {sample }}\right) / A_{\text {blank }}
$$

where, $A_{\text {blank }}$ and $A_{\text {sample }}$ are the absorbance values of the blank sample and of the test sample respectively, after 1 hour.

\section{Hydrogen peroxide scavenging capacity assay}

The hydrogen peroxide $\left(\mathrm{H}_{2} \mathrm{O}_{2}\right)$ scavenging capacity of lichen extracts was determined according to the method of Ruch et al [26], with some modifications [24]. A solution of $\mathrm{H}_{2} \mathrm{O}_{2}(2 \mathrm{mmol} / \mathrm{L})$ was prepared in phosphate buffer $(\mathrm{pH}$ 7.4). To obtain the test sample, $0.6 \mathrm{~mL}$ of phosphate buffer was added to $3.4 \mathrm{~mL}$ pondw eed extracts. The absorbance value of the reaction mixture was recorded at $230 \mathrm{~nm}$. Three replicates were made for each sample in comparisons with rutin as standard solution. The percentage of $\mathrm{H}_{2} \mathrm{O}_{2}$ scavenging capacity was calculated as:

$$
\% \text { scavenged } \mathrm{H}_{2} \mathrm{O}_{2}=\left[\left(\mathrm{A}_{0}-\mathrm{A}_{1}\right) / \mathrm{A}_{0}\right] \times 100
$$

where, $A_{0}$ is the absorbance of the control and $A_{\text {in }}$ is the absorbance in the presence of the sample or standards.

\section{Antimicrobial activity evaluation}

To test the sensitivity/resistance of various microorganisms to lichen extracts, the diffusion method (Kirby-Bauer) [27, 28] and agar dilution method [29] were used. All strains were obtained from the Clinic Laboratory of Faculty of Medicine and Pharmacy, Dunarea de Jos University of Galati: the G(-) Gram-negative bacteria Enterobacter hormaechei (ATCC 700323), Escherichia coli (ATCC 25922), Proteus mirabilis (ATCC 29906), Pseudomonas aeruginosa (ATCC 211853), Salmonella enteritidis (ATCC 13076); G(+) Gram-positive bacteria Staphylococcus aureus (ATCC 25293), Streptococcus pyogenes(ATCC 19615), Enterococcus casseliflavus (ATCC 25788) and fungus Candida albicans (ATCC 10259).

For each of the strains, the diffusion method was performed, in order to assess the sensitivity of the strains to acetone and alcoholic extracts, usnic acid dissolved in dimethyl sulfoxide (DMSO), antibiotics (gentamycin and pencillin) in case of bacteria and antifungal (nystatin) for fungi. The culture media used were: Müller Hinton (Gramnegative bacteria, Staphylococcus aureus), blood agar (Enterococcus casseliflavus, Streptococcus pyogenes) and solid Sabouraud medium for fungus. This method consists of the following steps: (i) inoculum preparation; (ii) inoculum seeding; (iii) blank disc soaking; (iv) micro tables and discs deposition; (v) incubating; (vi) reading. For each bacterial strain isolated in pure culture, an inoculum was prepared with the turbidity of $0.5 \mathrm{McF}$ arland $\left(1.5 \times 10^{8} \mathrm{CFU} /\right.$ $\mathrm{mL}$ ), the nephelometry being controled with Densi CHEK apparatus. Five identical colonies suspended in $3 \mathrm{~mL}$ saline solution for bacteria/fungus were used. The seeding was performed uniformly on the media surface. After seeding, plates were incubated for 5-10 minutes for the inoculum to be absorbed into the medium. Meanwhile the blank discs were soaked with $25 \mu$ l ethanol extract, acetone extract and usnic acid solution, respectively. The soaked disks and micro tablets of gentamycin, pencillin and nystatin of known concentrations ( $10 \mu \mathrm{g}, 100 \mathrm{U} . \mathrm{I}$.) were applied using a forceps by pressing gently on the surface of the seeded medium. In their application, a distance of $\sim 15 \mathrm{~mm}$ from the edge of the plate and $\sim 30 \mathrm{~mm}$ between micro tables/ discs was developed. After 10-15 min of application, the plates were incubated aerobically at $37^{\circ} \mathrm{C}$ for $24 \mathrm{~h}$. The antimicrobial compound impregnated on the disc diffuses in the medium and shows an inhibition zone of the culture around the disc, depending on its sensitivity. After incubation, only the plates with an increase in terms of culture purity and density were evaluated. The inhibition zone was measured 2-3 times in different directions, with a ruler. For transparent medium, the assessmentwas done directly on the bottom plate and in case of blood agar plates the measurement of inhibition zone diameter was obtained at the medium surface.

The dilution method was used to determine the sensitivity of the microorganism from the test sample indicating the concentration required to inhibit its development. In this way the minimum inhibitory concentration (MIC) was measured. Increasing dilutions of usnic acid dissolved in DMSO were prepared directly in saline solution. Equal amounts of the analyzed culture were seeded to determine the maximum dilution of the substance which inhibits the strain. The stock solution was prepared from usnic acid dissolved in DMSO whose initial concentration was $50 \mathrm{mg} / \mathrm{mL}$. Pseudomonas aeruginosa was the evaluated microorganism. An inoculum with the turbidity of 0.5 McFarland $\left(1.5 \times 10^{8} \mathrm{CFU} / \mathrm{mL}\right)$ was performed and controlled nephelometry using Densi CHEK apparatus. Five identical colonies were suspended in about $3 \mathrm{~mL}$ of saline solution to test the antimicrobial activity of bacteria. Equal amounts from the final solution were seeded into all dilutions of the usnic acid. For dilutions 10 test tubes were used and filled with $450 \mathrm{~mL}$ of saline solution, adding $2.50 \mu \mathrm{L}$ of usnic acid stock solution. After 
homogenization, $50 \mu \mathrm{L}$ were passed in the next test tube and so on until the tube 10 from which $50 \mu \mathrm{L}$ of solution were removed. The quantification was done after incubation at $37^{\circ} \mathrm{C}$ for $24 \mathrm{~h}$. The minimum inhibitory concentration (MIC) was measured by visual appreciation of the tube in which no bacterial growth was identified (the culture medium was clear). To appreciate the minimum bactericidal concentration (MBC), by observing the absence of bacterial growth, the inoculum was seeded from tubes 3 to 10 into Petri plates using Müller Hinton medium.

\section{Results and discussions}

\section{Chemical analysis of furan compounds}

Qualitative and quantitative evaluation of usnic acid from acetone extract was performed using IR spectroscopy and HPTLC technique.

\section{IR analysis}

FTIR spectra recorded for the acetone extract is shown in figure 1. From this spectrum, a band at $1690 \mathrm{~cm}^{-1}$ corresponding to a conjugated cyclic ketone groups $(\mathrm{C}=$ 0 ) was identified. Also, some weak bands at 1715 and $1678 \mathrm{~cm}^{-1}$ corresponding to the non-conjugated cyclic methyl ketones groups were detected. Characteristic signals of aryl alkyl ether group ( $\mathrm{C}-\mathrm{O}-\mathrm{C}$ ) were recorded at 1283 and $1072 \mathrm{~cm}^{-1}$.

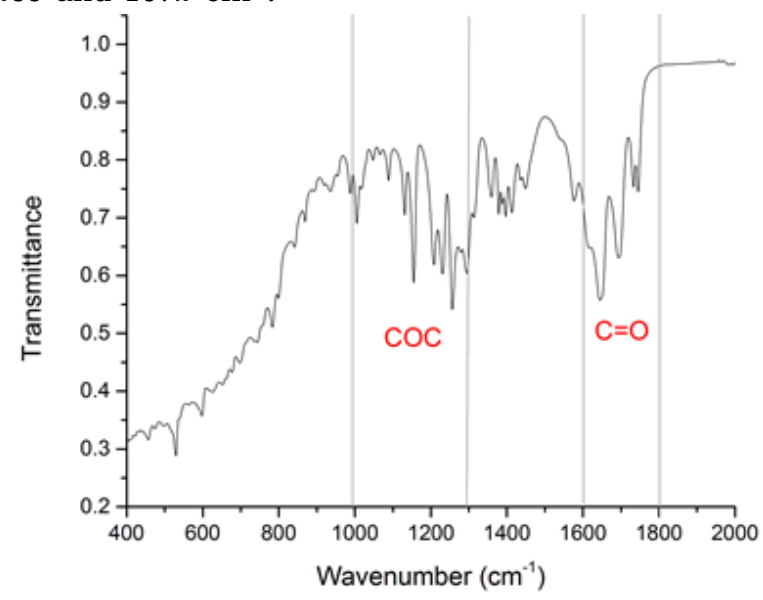

Fig.1. IR spectrum of acetone extract

\section{HPTLC analysis}

The presence of usnic acid in the structure of $C$. islandica was identified using higher pressure thin layer chromatography. The colored spots from the chromatographic plate with the Rf corresponding to usnic acid were detected at a wavelength of $237 \mathrm{~nm}$ (fig. 2).

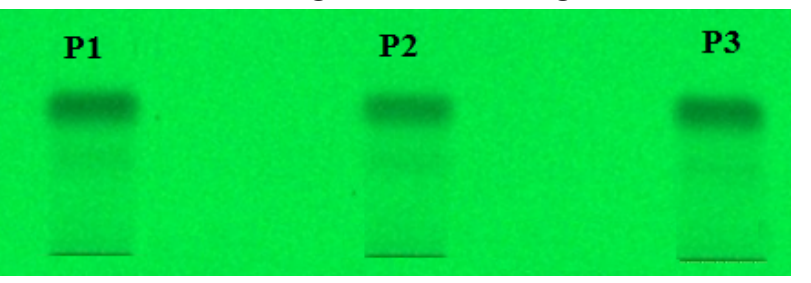

Fig. 2. Chromatogram of lichen extracts (acetone extract - P1 and ethanol extract - P2) and the standard solution of usnic acid (P3)

$R f$ value identified for the usnic acid (0.18) was used in the quantitative assessment of usnic acid by quantification of the usnic acid concentration in the acetone and ethanol extracts. The usnic acid concentration was measured by plotting the calibration curve of the standard solution of usnic acid (fig. 3).

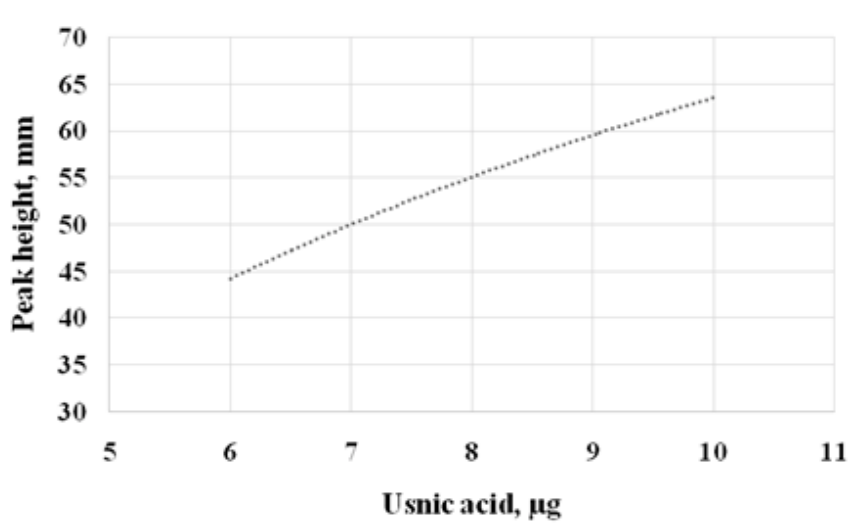

Fig. 3. Calibration curve of usnic acid $(R=0.9214, s d v=11.5 \%)$

The usnic acid concentration from the ethanol extract $(4.782 \mu \mathrm{g} / \mu \mathrm{L})$ and acetone extract $(5.600 \mu \mathrm{g} / \mu \mathrm{L})$, respectively was obtained by interpolation of this calibration curve. The highest concentration of usnic acid was found for acetone extract.

Biological activity of furan derivatives from $\mathrm{C}$. islandica lichen

Antioxidant activity

The determination of reducing power serves as an important indicator regarding to a potential antioxidant activity of the compound or mixture studied. Many studies have revealed that there is a direct correlation between the antioxidant activity and reducing power of plant components [30]. To measure the reducing power, the transformation of $\mathrm{Fe}^{3+}$ to $\mathrm{Fe}^{2+}$ in presence of the acetone and ethanol extracts was investigated using the method described by Yang, Guo and Yuan (2008), with some changes. The reducing capacity of samples in comparison with rutin solution, known for its notable antioxidantactivity is shown in figure 4 . A high absorbance of the reaction mixture indicates a higher reducing power.

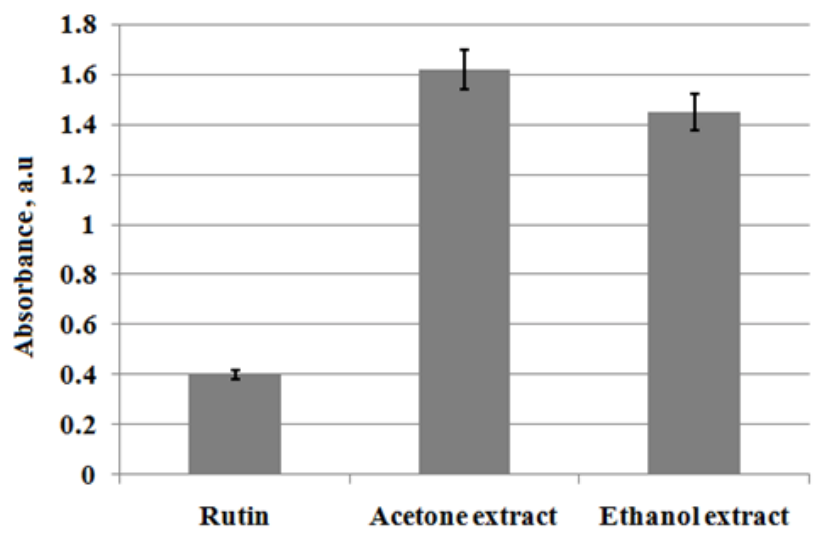

Fig. 4. Reducing power evaluation of Cetraria islandica extracts

This result suggests that $C$. islandica extracts have a remarkable potential to donate electrons to reactive free radicals, making them more stable species, non-reactive and ending the chain radical reaction.

The results expressed by percentage of DPPH scavenging are shown in figure 5 and varies thus: $18.62 \%$ for ethanol extract and $40.68 \%$ for acetone extract.

The scavenging capacity varies for the analyzed extracts and the results are presented in figure 6 .

Our results have shown that the percentage inhibition capacity ranged from $57.02 \%$ (ethanol extract) to $63.16 \%$ (acetone extract). Therefore, the acetone extract, that was shown to have a greater concentration of usnic acid, also 

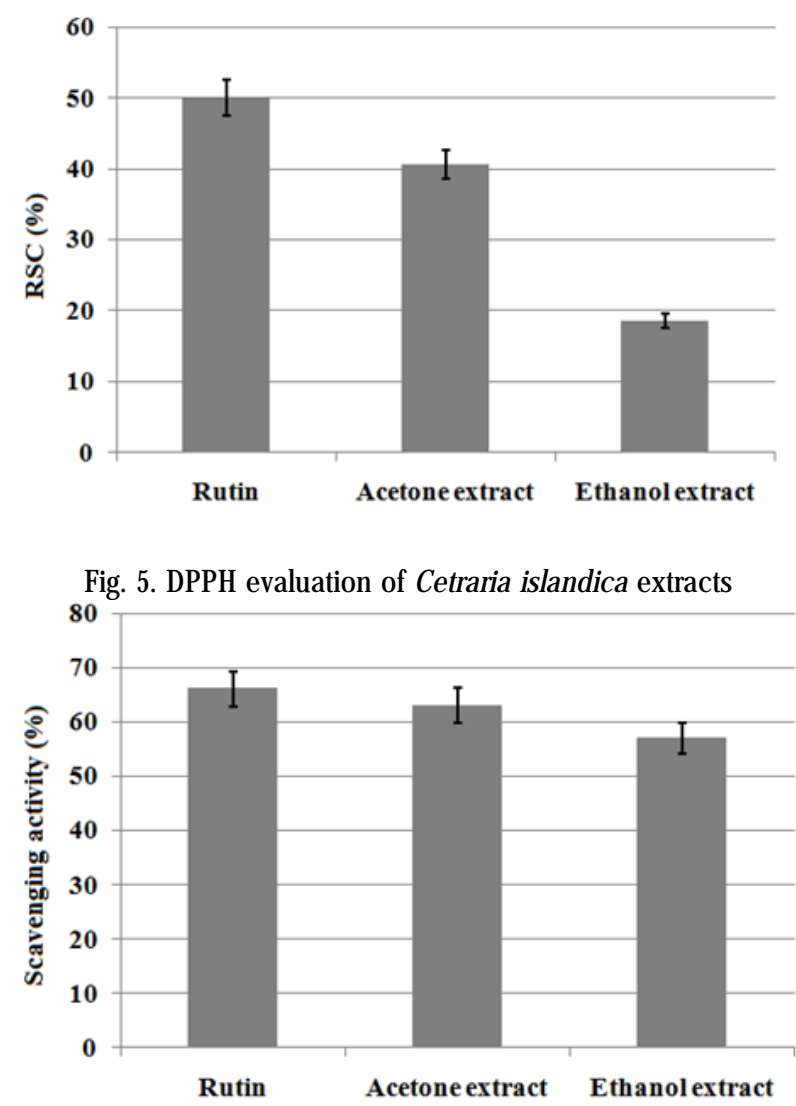

Fig. 6. Scavenging activity evaluation of Cetraria islandica extracts

exhibited higher reducing power and higher radical scavenging capacity than the ethanol extract.

\section{Antimicrobial activity}

The antimicrobial activity of $C$. islandica extracts was assessed using the diffusion method (Kirby-Bauer) and the dilution method. The diffusion method provides information on the resistance of plant material extracts against various microorganisms [31]. In this method, the following areas were evaluated: (i) inhibition zone diameters (area without microbial colonies, including the diameter of disc with antibiotic) (fig. 7a) and (ii) well-developed colonies appeared within of the inhibition zone (fig. 7b).

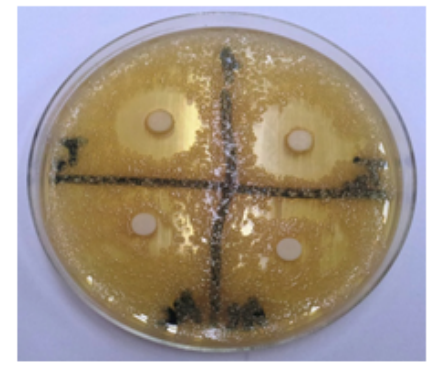

a

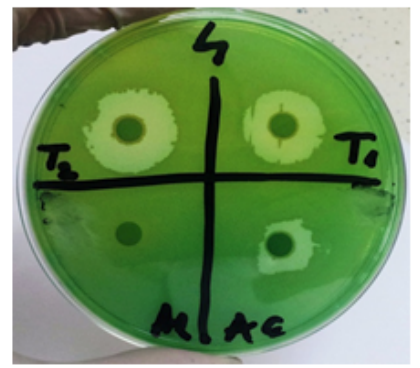

b
Fig. 7. (a). Sensitivity of Enterococcus casselifavus against lichen extracts; (b). Sensitivity of Pseudomonas aeruginosa against lichen extracts

Lichen extracts and usnic acid solution dissolved in dimethyl sulfoxide showed a significant inhibition activity on Gram-negative bacteria (fig. 8). So, the extracts and usnic acid have antibacterial activity on most Gramnegative strains considered in this study.

The acetone extract showed a greater antimicrobial activity on Enterobacter hormaechei bacteria compared with penicillin. For Proteus spp. bacteria, the ethanol extract was characterized by a superior antimicrobial activity

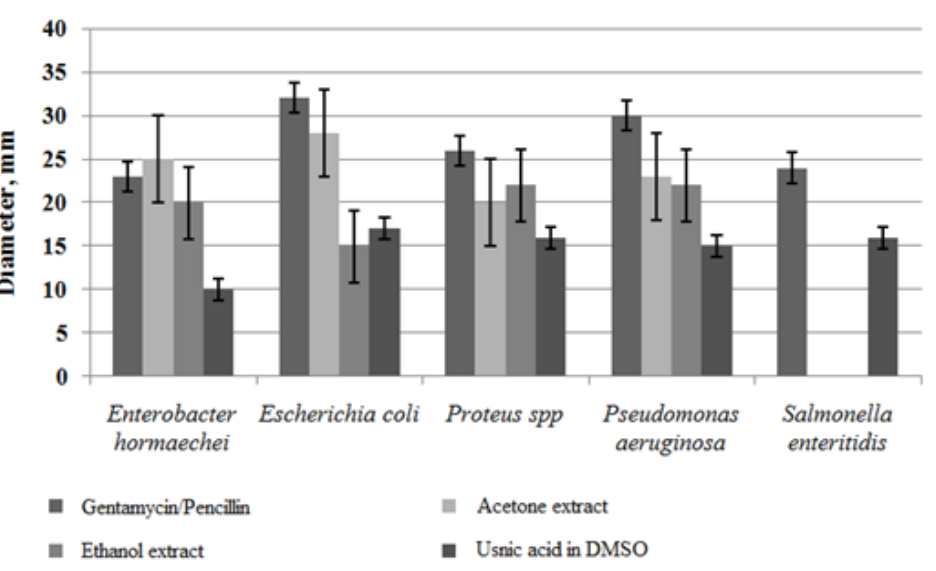

Fig. 8. Antimicrobial activity of the lichen extracts and usnic acid compared with the antibiotic on Gram-negative bacteria

compared to usnic acid and acetone extract, indicating that other bioactive compounds are responsible for this behavior. Except for the antibiotic, the usnic acid dissolved in dimethyl sulfoxide was the only tested compound which had antibacterial activity on Salmonella enteridis bacteria.

The antimicrobial activity of $C$. islandica extracts and usnic acid against some Gram-positive bacteria was evaluated by measuring the diameters of the inhibition zones around of the disc in $\mathrm{mm}$ (fig. 9).

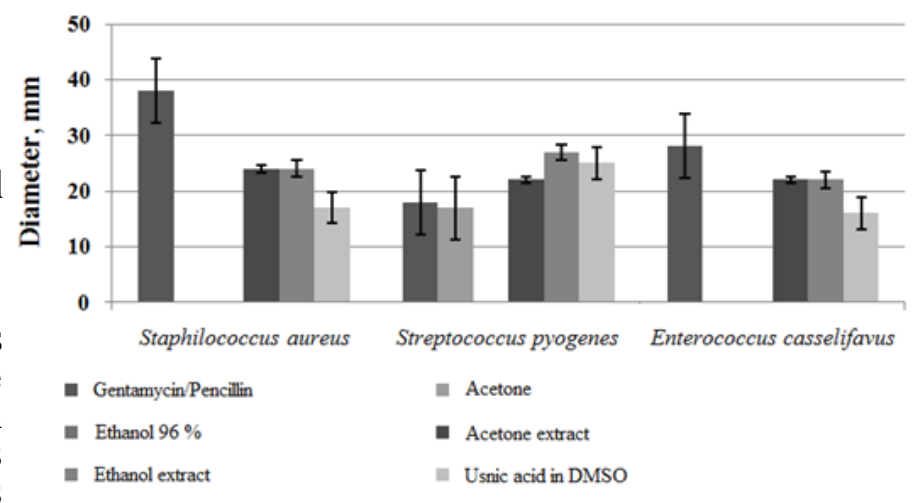

Fig. 9. Antimicrobial activity of Cetraria islandica extracts against Gram positive bacteria

Inhibition zones of the growth of Gram-positive bacteria were increased both for lichen extracts and for usnic acid for a content of $25 \mu \mathrm{L} / \mathrm{blank}$ disc. For Streptococcus pyogenes bacteria the results are different for each extract and antibiotic used. The ethanol extract has the highest antimicrobial potential (diameter of the inhibition zone of $27 \mathrm{~mm}$ ) compared to usnic acid (diameter of the inhibition zone of $25 \mathrm{~mm}$ ), the acetone extract (diameter of the inhibition zone of $22 \mathrm{~mm}$ ) and pencillin (diameter of the inhibition zone of $18 \mathrm{~mm}$ ). The antimicrobial potential of the ethanol extract was close to the one of pencillin. The acetone extracts showed an antibacterial activity identical to that of the ethanol extract against of the strain of the Staphylococcus aureus bacteria and Enterococcus casselifavus bacteria, respectively.

Dulger et al. (1998) investigated ethyl acetate, acetone, chloroform and ethanol extracts of $C$. islandica against different microorganisms by disc-diffusion method. They have found that $C$. islandica exhibited antimicrobial activity against some Gram-positive bacteria, but had no antimicrobial activity against Gram-negative bacteria and fungi [32]. Differences in the results could be explained by the difference in sensitivity of tested microorganisms, different methods of testing and the solvents used. These results could be expected due to the fact that numerous 
tests have proven that bacteria are more sensitive to antibiotics compared to fungi [33].

The antifungal activity of the lichen extracts and usnic acid against Candida albicans strain were assessed in comparison with the Nystatin activity (fig. 10).

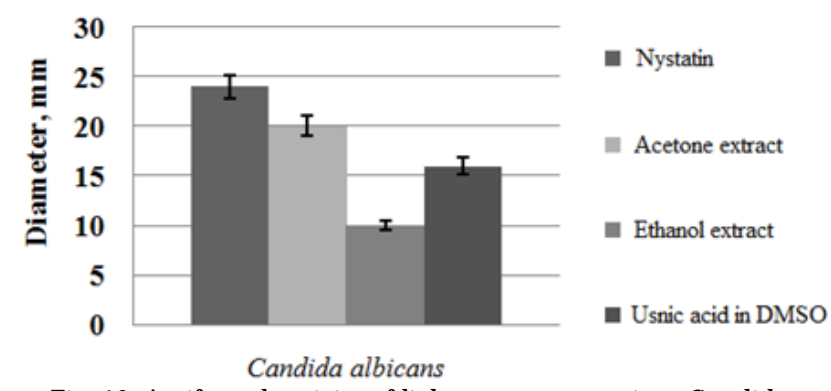

Fig. 10. Antifungal activity of lichen extracts against Candida albicans strain

By measuring the diameters of the inhibition zones around the disc, expressed in $\mathrm{mm}$, it was observed that the acetone extract (inhibition diameter of $20 \mathrm{~mm}$ ) has an antifungal activity against Candida albicans strain similar to that of Nystatin (inhibition diameter of $24 \mathrm{~mm}$ ), an elective fungal, followed by usnic acid (inhibition diameter of $16 \mathrm{~mm}$ ).

The reason for different sensitivity between fungi and bacteria could also be found in the difference in permeability of the cell wall. The cell walls of Gram-positive bacteria consist of peptidoglycan (murein) and teichoic acids, while the cell walls of Gram-negative bacteria consist of lipopolysaccharides and lipopoliproteins [34]. On the other hand, the cell walls of fungi consist of polysaccharides such as chitin and glucan [35].

\section{Antimicrobial activity using dilution method}

The minimum inhibitory concentration (MIC) and minimum bactericidal concentration (MBC) of usnic acid against Pseudomonas aeruginosa strain were measured using dilution method (fig. 11). The dilutions (from the stock solution) were prepared from 1:2 to $0.048: 50 \mathrm{mg} /$ $\mathrm{mL}$.

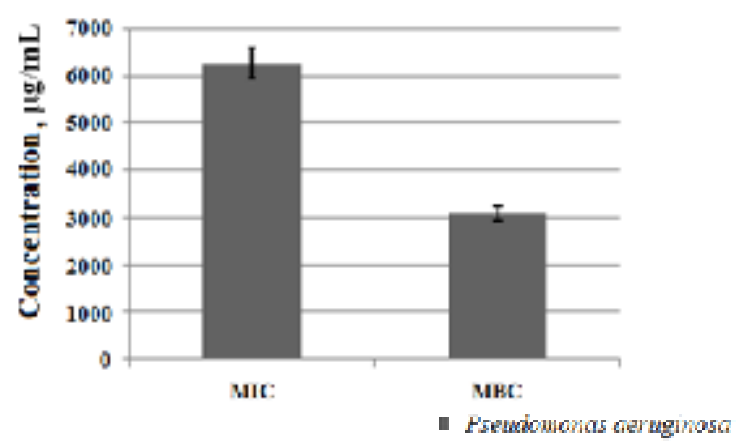

Fig. 11. Minimum inhibitory concentration (MIC) and minimum bactericidal concentration (MBC) determination. (concentration of usnic acid stock solution: $50 \mathrm{mg} / \mathrm{mL}$ ).

It was observed that usnic acid has antimicrobial activity against Pseudomonas aeruginosa, the MIC being $6250 \mu \mathrm{g} /$ $\mathrm{mL}$. The minimum bactericidal concentration $(3125 \mu \mathrm{g} /$ $\mathrm{mL}$ ) was appreciated by observing the absence of colonies growth seeded on Petri plates with Müller-Hinton medium from analysed samples.

Different lichens were screened for antimicrobial activity in search of new antimicrobial agents. Kosaniç et al. (2012a) found antimicrobial activity for the acetone extract of the lichens Umbilicaria crustulosa, U. cylindrica, and U. polyphylla [36]. Similar results were reported by Karthikai Devi et al. (2011) for different extracts extracted from the lichen Roccella belangeriana[37]. Goel etal. (2011) found that the lichen Parmotrema reticulatum had a strong antimicrobial effect [38].

\section{Conclusions}

Lichens are plants that contain in their structure many constituents and are therefore very capable of variation. So, it is very important to know the characteristic chemical components and the pharmacologically active compounds of the lichens.

The main goal of this study was to identify and extract the bioactive compounds with antioxidant and antimicrobial potential from $C$. islandica lichen.

The acetone and ethanol extracts were obtained using solid-liquid extraction method and the usnic acid was extracted from acetone extract by precipitation with benzene. Extract samples confirmed the presence of carbonyl compounds, usnic and salazinic acid in their composition, according to literature $[39,40]$.

The HPTLC analysis was able to provide useful qualitative and quantitative data for the quick determination of the usnic acid in the acetonic and ethanolic extract, therefore this technique being ideally suited for the analysis of botanical products.

Both acetone and ethanol extract showed a superior antioxidant activity compared to other standard compounds used to evaluate the antioxidant activity.

The assessment of the antimicrobial activity of $C$. islandica extracts by diffusion method (Kirby-Bauer) and dilution method highlighted that both extracts and pure usnic acid have activity against certain Gram-positive and Gram-negative bacteria and fungi such as Candida albicans. Antimicrobial activity depends on the solvent and microbial strain used. The acetone extract has a better antimicrobial activity compared to penicillin against Streptococcus pyogenes bacteria.

The lichen extracts, according to the technology adopted, could be used as the basis of some pharmaceutical formulations due to pharmacological potential of biological active compounds from $C$. islandica species.

Acknowledgements: : This work was supported by a grant of the Romanian National Authority for Scientific Research, CNCS-UEFISCDI, project number PN-II-ID-PCE-2011-3- 0226 and CENTRUL ROMÂN PENTRU MODELAREA SISTEMELOR RECIRCULANTE DE ACVACULTURÃ, Axa 2 POSCCE, operapiunea 02.2.1 - Dezvoltarea infrastructurii $C-D$ existente $-i$ crearea de noi infrastructuri $C-D$, 20142015.

\section{References}

1. MITROVIC, T., STAMENKOVIC, S., CVETKOVIC, V., NIKOLIC, M., TOSIC, S., STOJICIC, D., Biologica Nyssana, 2, no. 1, 2011, p. 1.

2. KANTHETI, P., IGOLI, J.O., GRAY, A.I, CLEMENTS, C.J ., SINGLA, R.K., WebmedCentral Pharmaceutical Sciences, 3, no. 11, 2012, p. 1. 3. PODTERAB, A., Pharmaceutical Chemistry J ournal, 42, no. 10, 2008, p. 582.

4. KARUNARATNE, V., BOMBUWELA, K., THADHANI, V., J ournal of the National Science Foundation of Sri Lanka, 33, no. 3, 2005, p. 169.

5. BOUSTIE, J., TOMASI, S., GRUBE, M., Phytochemistry Reviews, 10, 2011, p. 287.

6. YAMAMOTO, Y., HARA, K., KAWAKAMI, H., KOMINE, M., Recent Advances in Lichenology, 2, 2015, p. 181.

7. GOMEZ-SERRANILLOS, M.P., FERNANDEZ-MORIANO, C., GONZALEZBURGOS, E., DIVAKAR, P.K., CRESPO, A., RSC ADVANCES, 4, 2014, p. 59017.

8. LAUTERWEIN, M., OLTHINGER, M., BELSNER, K., Antimicrobial Agents and Chemotherapy, 39, no. 11, 1995, p. 2541.

9. SHRESTHA, G., CLAIR, L.L.St., Phytochemistry Reviews, 12, 2013, p. 229. 
10. ZAMBARE, V.P., CHRISTOPHER, L.P., Pharmaceutical Biology, 50, no. 6,2012, p. 778.

11. KOSANIC, M., RANKOVIC, B., Lichen Secondary Metabolites, Ed. Springer International Publishing Switzerland, 2015, p. 105-125.

12. BUCUKOGLU, T.B., ALBAYRAK, S., HALICI, M.G., TAY, T., J ournal of Food Processing and Preservation, 37, 2013, p. 1103.

13. BESSADOTTIR, M., SKULADOTTIR, E.A., GOWAN, S., ECCLES, S., OMARSDOTTIR, S., OGMUNDSDOTTIR, H.M., Phytomedicine, 21, 2014, p. 1717.

14. TIWARI, P., RAI, H., UPRETI, D.K., TRIVEDI, S., SHUKLA, P., Nature and Science, 9, no. 9, 2011, p. 167.

15. LOHEZIC-LE DEVEHAT, F., LEGOUIN, B., COUTEAU, C., BOUSTIE, J., COIFFARD, L., J ournal of Photochemistry and Photobiology $B$ : Biology, 120, 2013, p. 17.

16. KOSANIC, M., RANKOVIC, B., Kragujevac J ournal of Science, 32, 2010, p. 65.

17. KOSANIC, M., RANKOVIC, B., VUKOJ EVIC, J., Food Science Technology, 48, no. 5. 2011, p. 584.

18. THELL, A., CRESPO, A., DIVAKAR, P.K., KARNEFELT, I.K., LEAVITT, S.D., LUMBSCH, H.T., SEAWARD, M.R.D., Nordic J ournal of Botany, 30, 2012, p. 641.

19. MANIJ LOVIC, N., RANKOVIC, B., KOSANIC, M., VASILJ EVIC, P., Phytomedicine, 19, no. 13, 2012, p. 1166.

20. MITROVIC, T., STAMENKOVIC, S., TOSIC, S., CVETKOVIC, V., International J ournal of Molecular Sciences, 12, no. 8, 2011, p. 5428. 21. FERARU, D.L., MEGHEA, A., BADEA, N., Rev. Chim. (Bucharest), 64, no. 1, 2013, p. 74.

22. YANG, J., GUO, J., YUAN, J., LWT- Food Science and Technology, 41, no. 6, 2008, p. 1060.

23. BOZIN, B., MIMICA-DUKIC, N., SAMOJ LIK, I., GORAN, A., IGIC, R., Food Chemistry, 111, 2008, p. 925.

24. LUPOAE, P., CRISTEA, V., BORDA, D., LUPOAE, M., GURAU, G., DINICA, R.M., Journal of Oleo Science, 64, no. 10, 2015, p. 1111.

25. PAPUC, C., CRIVINEANU, M., NICORESCU, V., PAPUC, C., PREDESCU, C., Rev. Chim. (Bucharest), 63, no. 12, 2012, p. 1198.
26. RUCH, R.J ., CHENG, S.J ., KLAUNING, J.E., Carcinogenesis, 10, 1989, p. 1003.

27. BENSON, H.J., In: Microbiological applications: laboratory manual in general microbiology, 7th edn., Ed. McGraw Hill, Boston, Massachusetts, 1998, p. 139-141.

28. JIANU, C., MISCA, C., POP, G., RUSU, L.C., ARDELEAN, L., GRUIA, A.T., Rev. Chim. (Bucharest), 63, no. 12, 2012, p. 641.

29. WIEGAND, I., HILPERT, K., HANCOCK, R.E.W., Nature Protocols, 3, 2008, p. 163.

30. YILDIRIM, A., MAVI, A., KARA, A.A., J ournal of Agricultural and Food Chemistry, 49, no. 8, 2001, p. 4083.

31. BAUER, A.W., KIRBY, W.M.M., SHERRIS, J.C., TURCK, M., American J ournal of Clinical Pathology, 36, 1966, p. 493.

32. DULGER, B., GUCIN, F., ASLAN, A., Turkish J ournal of Biology, 22, 1998, p. 111.

33. HUGI, W.B., RUSSEL, A.D., Pharmaceutical microbiology, 3rd edn., Ed. Blackwell Scientific Publications, Oxford, 1983.

34. HEIJ ENOORT, J., Glycobiology, 11, 2001, p. 25.

35. FARKAS, V., Folia Microbiologica, 48, 2003, p. 469.

36. KOSANIC, M., RANKOVIC, B., STANOJ KOVIC, T., Journal of Food Science, 77, 2012a, p. T20.

37. KARTHIKAI, D.G., ANANTHARAMAN, P., KATHIRESAN, K., BALASUBRAMANIAN, T., Indian Journal of Geo-Marine Sciences, 40, 2011, p. 449.

38. GOEL, M., DUREJ A, P., RANI, A., UNIYAL, P.L., LAATSCH, H., J ournal of Agricultural and Food Chemistry, 59, 2011, p. 2299.

39. YOSHIMURA, I., HUNECK, S., Identifications of lichen substances, Ed. Springer-Verlag, Berlin Heidelberg 1996, p. 11 - 123.

40. NUNES, S.P., BEZERRA, S.M., COSTA, L.P., CORDEIRO CARDOSO, J., ALBUQUERQUE, R.L.C., RODRIGUES, M.O., BARIN, G.B., AMARAL DA SILVA, F., ARAUJ O, A.A.S., J ournal of Thermal Analysis and Calorimetry, 99, 2010, p. 1011.

Manuscript received: 17.02 .2017 